\title{
Screening Mangrove Endophytic Fungi for Antimalarial Natural Products
}

\section{Laurent Calcul $^{1}$, Carrie Waterman ${ }^{1}$, Wai Sheung Ma ${ }^{1}$, Matthew D. Lebar ${ }^{1}$, Charles Harter ${ }^{1}$, Tina Mutka ${ }^{2}$, Lindsay Morton ${ }^{2}$, Patrick Maignan ${ }^{2}$, Alberto Van Olphen ${ }^{2}$, Dennis E. Kyle ${ }^{2}$, Lilian Vrijmoed $^{3}$, Ka-Lai Pang ${ }^{4}$, Cedric Pearce ${ }^{5}$ and Bill J. Baker ${ }^{1,6, *}$}

1 Department of Chemistry, University of South Florida, 4202 E. Fowler, CHE 205, Tampa, FL 33620, USA; E-Mails: calcul@ usf.edu (L.C.); waterman@ aesop.rutgers.edu (C.W.); wma2@mail.usf.edu (W.S.M.); mlebar@chemistry.harvard.edu (M.D.L.); csharter41@gmail.com (C.H.)

2 Department of Global Health, University of South Florida, 3720 Spectrum Blvd., Suite 304, Tampa, FL 33612, USA; E-Mails: tmutka@ @ealth.usf.edu (T.M.); wst8@cdc.gov (L.M.); pmaignan@mail.usf.edu (P.M.); avanolph@health.usf.edu (A.V.O.); dkyle@health.usf.edu (D.E.K.)

3 Department of Biology and Chemistry, City University of Hong Kong, 83 Tat Chee Avenue, Hong Kong, China; E-Mail: bhlilian@ @ityu.edu.hk

4 Institute of Marine Biology and Center of Excellence for the Oceans, National Taiwan Ocean University, 2 Pei-Ning Road, Keelung 20224, Taiwan; E-Mail: klpang@ntou.edu.tw

5 Mycosynthetix, Inc., 505 Meadowlands Drive, Suite 103, Hillsborough, NC 27278, USA; E-Mail: cpearce@mycosynthetix.com

6 Center for Drug Discovery and Innovation, University of South Florida, 3720 Spectrum Blvd., Suite 303, Tampa, FL 33612, USA

* Author to whom correspondence should be addressed; E-Mail: bjbaker@usf.edu; Tel.: +1-813-974-9606; Fax: +1-813-905-9933.

Received: 12 September 2013; in revised form: 27 November 2013 / Accepted: 28 November 2013 / Published: 12 December 2013

\footnotetext{
Abstract: We conducted a screening campaign to investigate fungi as a source for new antimalarial compounds. A subset of our fungal collection comprising Chinese mangrove endophytes provided over 5000 lipophilic extracts. We developed an accelerated discovery program based on small-scale cultivation for crude extract screening and a high-throughput malaria assay. Criteria for hits were developed and high priority hits were subjected to scale-up cultivation. Extracts from large scale cultivation were fractionated and these
} 
fractions subjected to both in vitro malaria and cytotoxicity screening. Criteria for advancing fractions to purification were developed, including the introduction of a selectivity index and by dereplication of known metabolites. From the Chinese mangrove endophytes, four new compounds $(\mathbf{1 4}-\mathbf{1 6}, \mathbf{1 8})$ were isolated including a new dimeric tetrahydroxanthone, dicerandrol D (14), which was found to display the most favorable bioactivity profile.

Keywords: fungi; endophytes; mangroves; malaria; cytotoxicity; high-throughput

\section{Introduction}

Mangrove plants and their associated microfauna have been a rich source of bioactive molecules [1-3], though only limited [4-6] antimalarial screening of this chemodiversity source has been reported. Mangrove forests are fascinating and complex ecosystems [7]. They serve coastal populations worldwide by protecting shorelines from storm surge and erosion, through filtration/remediation of terrestrial runoff, and as nurseries for important fisheries, among other useful roles. Yet these marine margin communities are under constant threat of clearing from real estate development, fish-pond farming, and even for their wood to support cooking hearths in poor, rural communities. The World Wildlife Foundation [8] reports that 35\% of global mangrove communities have disappeared in the last two decades alone [9,10], and one in six species are in danger of extinction [11,12]. Similar to the more visible coral reef and rainforest ecosystems, a better understanding of the biotechnological value of marine margin communities may engender respect and enthusiasm for conservation efforts. We report here a screening campaign using mangrove endophytic fungi from the Mai Po Nature reserve, Hong Kong, and Hainan Island, Taiwan, as sources for new antimalarial compounds.

\section{Results and Discussion}

\subsection{Strategy}

Our strategy to miniaturize fungal cultures provided for an economy of scale that allowed us to rapidly produce small quantities of crude extracts for screening. Using a robust and validated Plasmodium falciparum (3D7, a drug sensitive strain) screen [13], 96-well plated crude extract screening data was available to us weekly. Our workflow (Scheme 1) included decision points based on crude extract activity, leading to scaled-up cultivation, then new decision points based both on $\mathrm{IC}_{50}$ values of parasite and mammalian (A549) cytotoxicity. All purified metabolites were then screened for bioactivity and characterized either by LC/MS dereplication with verification by NMR, or by de novo structure analysis. Over a two year period we cultured, screened and prioritized approximately 50,000 total fungal extracts, and conducted fractionation, re-screening, and purification on approximately $10 \%$ of those. Such an intensive effort requires trade-offs; we chose, for example, to conduct a single extract of freeze-dried cultures since it yielded sufficient material for screening, and we chose to forego verification of activity in scaled-up cultures, since fractionation was quick and 
fraction activity was more important than extract activity. Similarly, dereplication of known compounds was done late in the workflow. We reasoned that previously published compounds were still of interest to us, and even nuisance compounds might mask compounds of interest, so we chose to dereplicate only at the purification step (end) of the workflow. Such sharp focus on a bioactivity criterion (Scheme 1) left many potentially useful fractions along the workflow, fractions which will be deconvoluted in ensuing studies.

Scheme 1. Sample workflow and decision points $(P f=$ Plasmodium falciparum $)$.

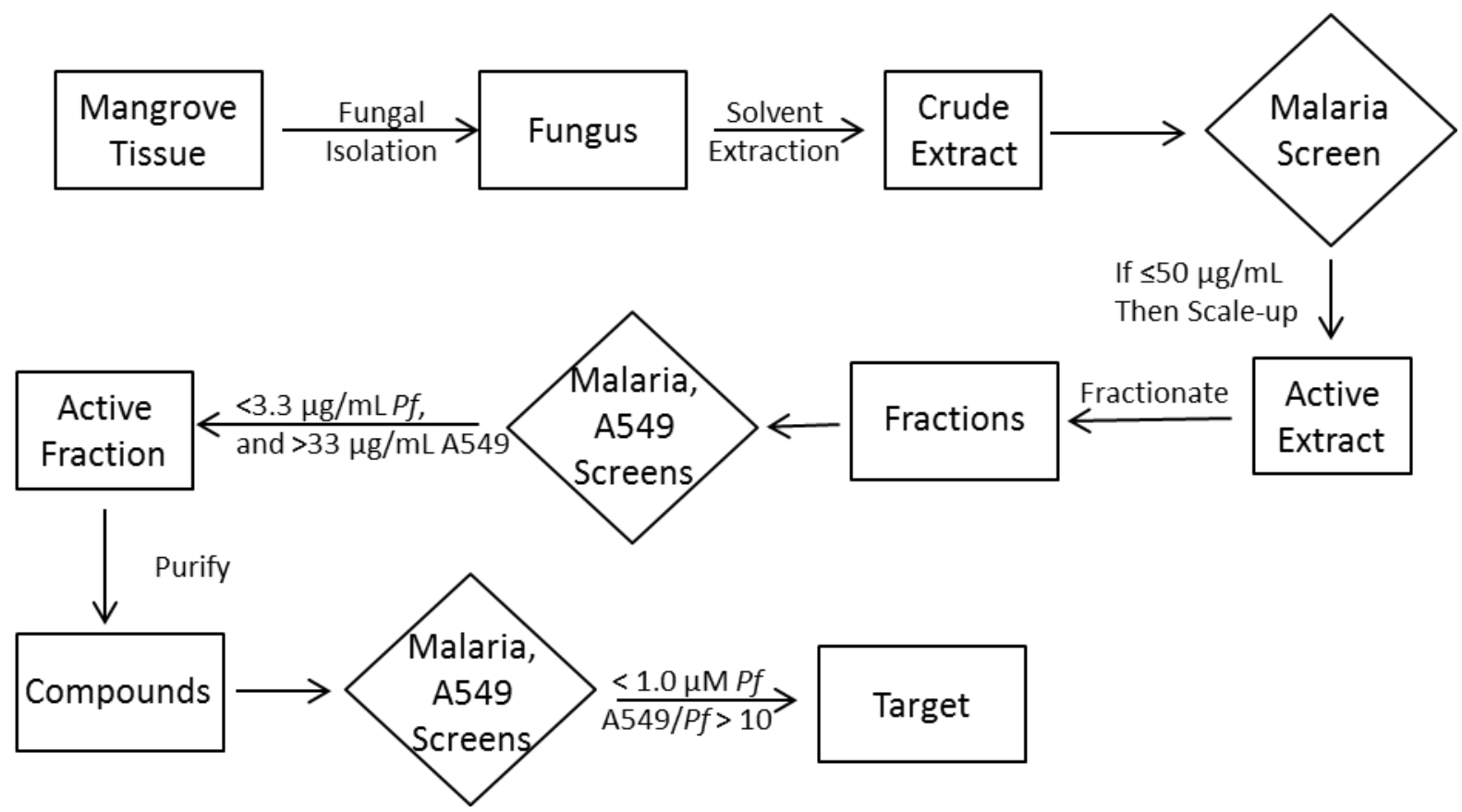

\subsection{Fungal Isolation and Fermentation}

Hong Kong and Taiwan have a similar subtropical climate and harbor many species of mangrove trees along the coastline where there is inundation of estuarine waters. Kandelia obovata and Avicennia marina are the dominant tree species in both healthy mangrove areas of Hong Kong and Taiwan while Lumnitzera racemosa is only found in Hong Kong mangrove communities. The endophytic fungal strains used in the study were isolated from surface sterilized plant tissues, using either $4 \%$ sodium hypochlorite [14] or $75 \%$ ethanol combined with 5\% sodium hypochlorite solution [15]. Leaf and bark tissues of A. marina, K. obovata and L. racemosa were studied. A total of 5486 fungi were isolated and cultivated for screening.

\subsection{Extraction, Plating and Screening of Miniaturized Cultures}

Freeze dried fungal mycelia were extracted with $15 \mathrm{~mL}$ of dichloromethane/methanol (1:1) for $24 \mathrm{~h}$ then transferred to a $20 \mathrm{~mL}$ scintillation vials arranged in $8 \times 12$ arrays where they were air dried and taken up in DMSO to approximately $30 \mathrm{mg} / \mathrm{mL}$. After transfer of $100 \mu \mathrm{L}$ aliquots into 96-well plates, screening at two concentrations ( 5 and $50 \mu \mathrm{g} / \mathrm{mL}$ ) using our previously published protocol [13] was conducted. Samples were prioritized as Active if they inhibited 3D7 by $\geq 67 \%$ at $5 \mu \mathrm{g} / \mathrm{mL}$, and Partially Active if there was $>67 \%$ inhibition at $50 \mu \mathrm{g} / \mathrm{mL}$, leading to approximately $0.6 \%$ extracts 
categorized as Active, 5\% Partially Active, and more than 90\% inactive. We advanced all Active extracts and $10 \%$ of the Partially Active into scale-up cultivation studies.

\subsection{Chromatographic Separation, Screening and Structure Elucidation}

Freeze-dried biomass from $2 \mathrm{~L}$ cultures were exhaustively extracted with dichloromethane/methanol (1:1) and applied to Combiflash ${ }^{\circledR}$ MPLC cartridges based on the manufacturers recommendation of cartridge size to analyte mass. A linear gradient from hexane to ethyl acetate and then methanol was conducted, collecting ten to twelve fractions/extract. Fractions were concentrated and re-submitted for 3D7 screening, and cytotoxicity screening against A549 human lung adenocarcinoma epithelial cells followed. The cytotoxicity screen introduced a new decision point whereby fractions and purified compounds had to exceed a threshold selectivity index (A549 activity/3D7 activity) of 10. Fractions were advanced to HPLC if their 3D7 activity was $<3.3 \mu \mathrm{g} / \mathrm{mL}$ and they met the selectivity index criterion, although priority was initially given to fractions with $<1.1 \mu \mathrm{g} / \mathrm{mL}$ to focus on the most promising fractions first.

Purified compounds were first dereplicated using mass and ${ }^{1} \mathrm{H}$ NMR data searched against AntiBase and SciFinder databases. For new compounds, full spectroscopic data sets $\left({ }^{1} \mathrm{H},{ }^{13} \mathrm{C}\right.$, DEPT, COSY, HSQC, HMBC, NOESY, HRMS) were acquired and analyzed to arrive at structural assignments.

\subsection{Fungal Chemistry and its Bioactivity}

Of the 5486 fungi tested against $P$. falciparum, 266 were Partially Active ( $\sim 5)$ and 34 were Active $(\sim 0.6 \%)$. Of these, 58 samples were scaled-up and subjected to MPLC fractionation. A total of 103 MPLC fractions were identified for purification, and 18 compounds identified either through dereplication or structure analysis (Figure 1).

\subsubsection{Mycotoxins}

Mycotoxins proved to be the nuisance compounds in this study. Eight cytochalasins (1-8) and two trichothecenes $(\mathbf{9}, \mathbf{1 0})$ were dereplicated (Figure 2) from eight different fungal strains (Table 1), though others were not pursued to purity. All structures reported here bore spectroscopic data (ESIMS, ${ }^{1} \mathrm{H}$ NMR) that agreed well with published [16-20] data. While often displaying potent antimalarial activity (Table 1), cytostatic activity that was not apparent in cytotoxicity screening precludes use of these toxins as drugs. Nonetheless, and in support of our decision to dereplicate late in the workflow, one trichothecene from another source remains one of the most promising leads of the project (work in progress). 
Figure 1. Summary of the screening results.

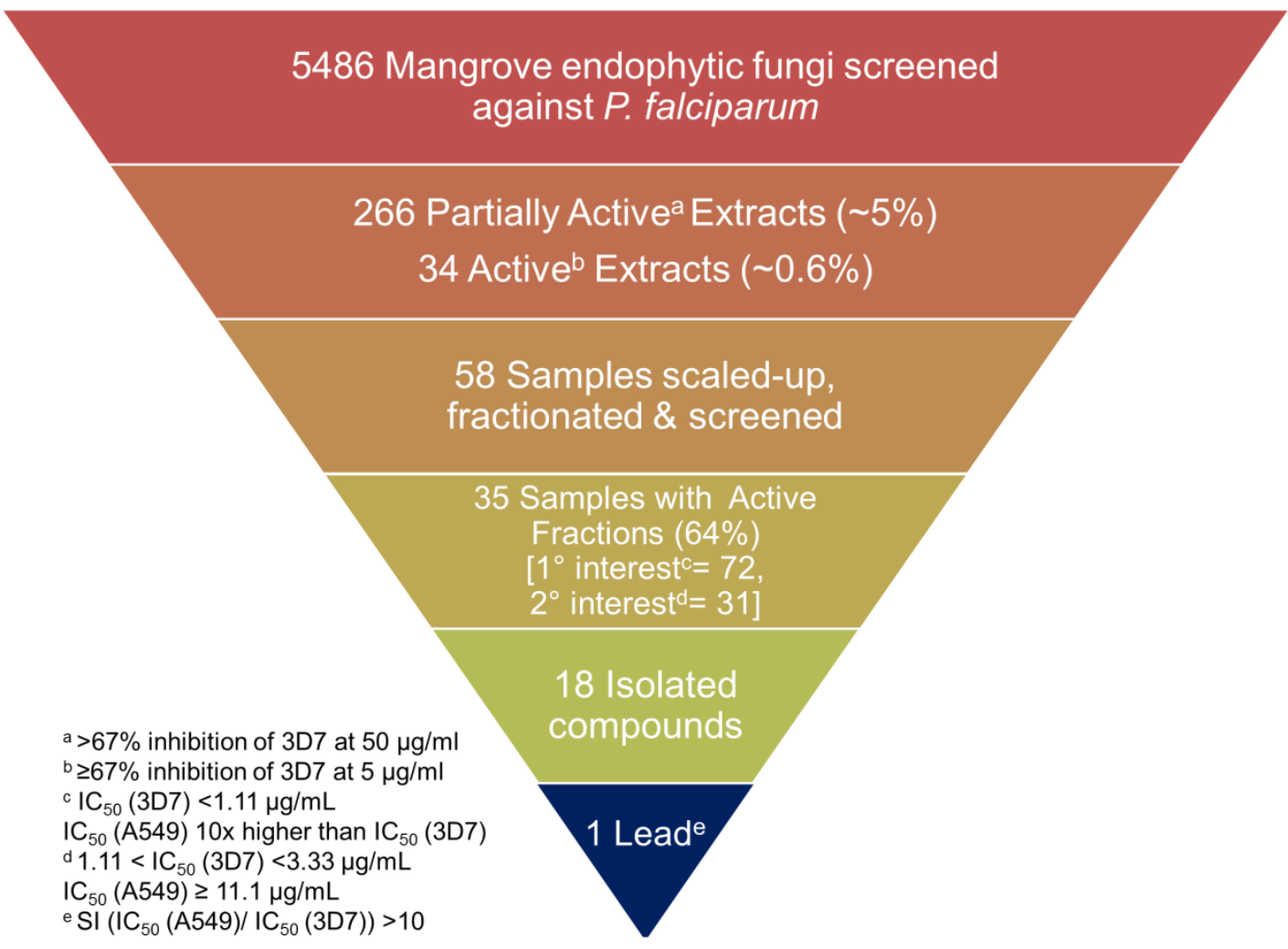

Figure 2. Mycotoxins from mangrove endophytes.

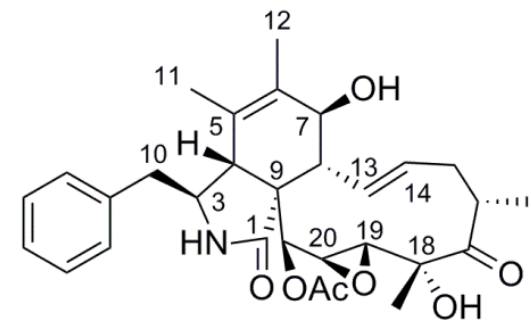

1

2,19-20 double bond

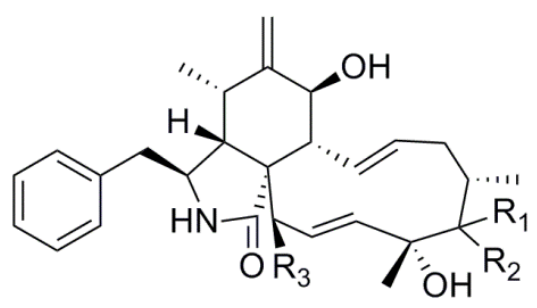

4, $\mathrm{R}_{1}=\mathrm{R}_{2}=\mathrm{O}, \mathrm{R}_{3}=\mathrm{OAc}$

5, $\mathrm{R}_{1}=\mathrm{R}_{2}=\mathrm{H}, \mathrm{R}_{3}=\mathrm{OAC}$

6, $\mathrm{R}_{1}=\mathrm{R}_{2}=\mathrm{H}, \mathrm{R}_{3}=\mathrm{OH}$

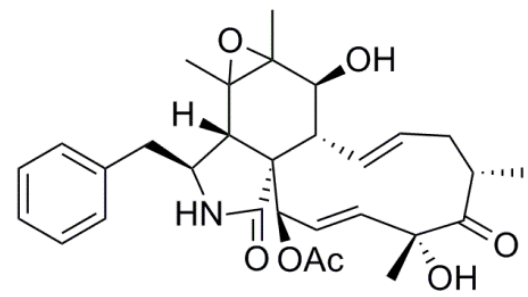

3

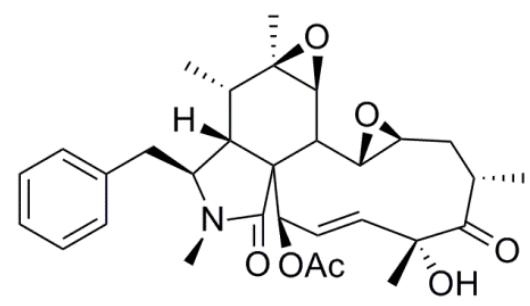

7

8,13-14 double bond

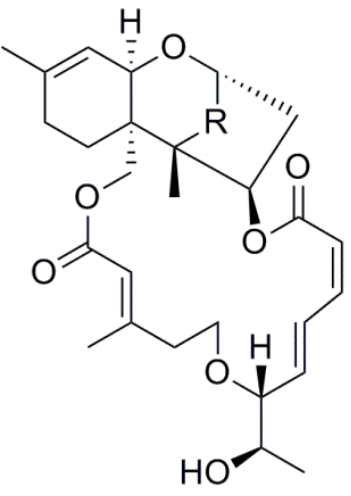

$9, \mathrm{R}=$<smiles>CCC(C)C(C)O</smiles>

10, $\mathrm{R}=$<smiles>C=C(CCCCCCC)C(=O)OC</smiles> 
Table 1. Compound summary and the associated anti-malarial activity against Plasmodium falciparum (3D7) and cytotoxicity against A549 cells.

\begin{tabular}{|c|c|c|c|c|c|}
\hline \multirow{2}{*}{ Group } & \multirow{2}{*}{ Cpd } & \multicolumn{2}{|c|}{$\mathrm{IC}_{50}(\mathrm{nM})$} & \multirow{2}{*}{$\frac{\text { S.I. }}{\text { A549/3D7 }}$} & \multirow{2}{*}{ Source (Taxonomic Identification) } \\
\hline & & 3D7 & A549 & & \\
\hline \multicolumn{6}{|l|}{ Mycotoxin } \\
\hline \multirow[t]{8}{*}{ Cytochalasin } & 1 & $<20$ & $\mathrm{ND} *$ & - & CY-5286 (Diaporthe sp.) \\
\hline & 2 & 136 & $\mathrm{ND} *$ & - & CY-5331 (Xylaria sp.) \\
\hline & 3 & $<20$ & $\mathrm{ND} *$ & - & CY-5368 (Verticillium sp.) \\
\hline & 4 & 25.8 & $\mathrm{ND} *$ & - & $\begin{array}{l}\text { CY-5286 (Diaporthe sp.), CY-6884 (Xylaria sp.), } \\
\text { NTOU-3332 (Xylaria sp.), NTOU-1430 (Xylaria sp.) }\end{array}$ \\
\hline & 5 & $<20$ & $\mathrm{ND} *$ & - & CY-5286 (Diaporthe sp.) \\
\hline & 6 & $<20$ & $\mathrm{ND} *$ & - & CY-5286 (Diaporthe sp.) \\
\hline & 7 & 290 & $\mathrm{ND} *$ & - & CY-5331 (Xylaria sp.) \\
\hline & 8 & 26 & $\mathrm{ND} *$ & - & CY-5331 (Xylaria sp.) \\
\hline \multirow[t]{2}{*}{ Trichothecene } & 9 & $<20$ & $<200$ & - & $\mathrm{CY}-3923^{\dagger}$ \\
\hline & 10 & $<20$ & $<200$ & - & $\mathrm{CY}-3923^{\dagger}$ \\
\hline \multirow[t]{6}{*}{ Polyketide } & 11 & 36,000 & $>38,700$ & - & NTOU-1455 (Xylaria sp.) \\
\hline & 12 & $>48,500$ & $>48,500$ & - & NTOU-2009 (Phomopsis sp.) \\
\hline & 13 & $>25,000$ & $>25,000$ & - & CY-5188 (Diaporthe sp.) \\
\hline & 14 & 600 & 7800 & 13 & CY-5188 (Diaporthe sp.) \\
\hline & 15 & $>25,000$ & $>25,000$ & - & CY-5286 (Diaporthe sp.) \\
\hline & 16 & $>25,000$ & $>25,000$ & - & CY-5286 (Diaporthe sp.) \\
\hline \multirow[t]{2}{*}{ Lipid } & 18 & $>25,000$ & $>25,000$ & - & CY-5331(Xylaria sp.) \\
\hline & 19 & $>25,000$ & $>25,000$ & - & CY-6884 (Xylaria sp.) \\
\hline \multirow[t]{3}{*}{ Control } & $\mathbf{C Q}$ & 4.5 & $>25,000$ & - & \\
\hline & ATO & 0.3 & $>25,000$ & - & \\
\hline & DHA & 0.8 & $>25,000$ & - & \\
\hline
\end{tabular}

S.I., selectivity index; * cytotostatic (recorded as lack of cell proliferation without cell death); ${ }^{\dagger}$ Not identified; ND, not determined; CQ, chloroquine; ATO, atovaquone; DHA, dihydroartemisinin.

\subsubsection{Polyketides}

Six polyketides were found in our Chinese endophytic fungi (Figure 3). Two previously reported isolates, acremonisol A (11) [21] and 3,5-dimethyl-8-methoxy-3,4-dihydroisocoumarin (12) [22,23], were devoid of antimalarial activity but derived from fractions found active due to the presence of cytochalasin D (4). Dicerandrol B (13) and a previously unreported derivative, named here as dicerandrol D (14), were found from a strain of Diaporthe sp. (CY-5188). Further work on a related active extract produced two further unreported compounds, 15 and 16 [24], from another strain of Diaporthe (CY-5286). Dicerandrol D (14) displayed nanomolar antimalarial activity and a low cytotoxicity with a selectivity index of 13 (Table 1). 
Figure 3. Polyketide chemodiversity from Chinese mangrove endophytes.<smiles>CCCc1c(Cl)c(OC)cc(OC)c1C(=O)O</smiles>

11<smiles>COc1ccc(C)c2c1C(=O)O[C@@H](C)C2</smiles>

12

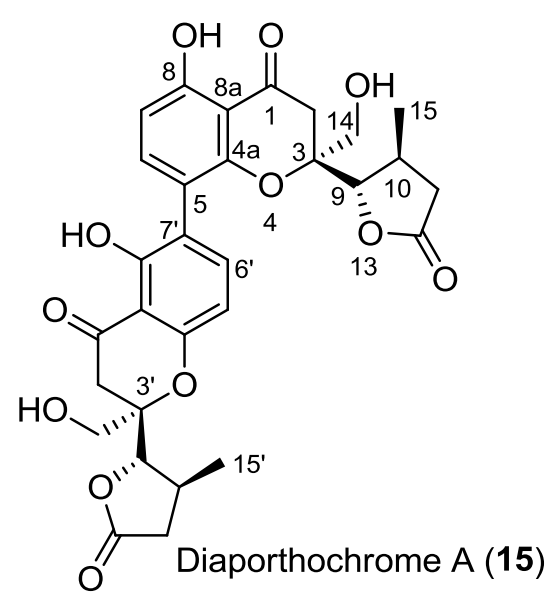

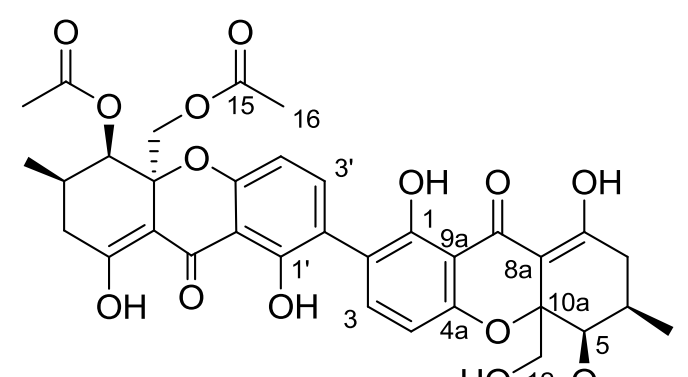

13: $10 \mathrm{a}, \mathrm{C}_{12}-\alpha$

14: $10 \mathrm{~b}, \mathrm{C}_{12}-\beta$

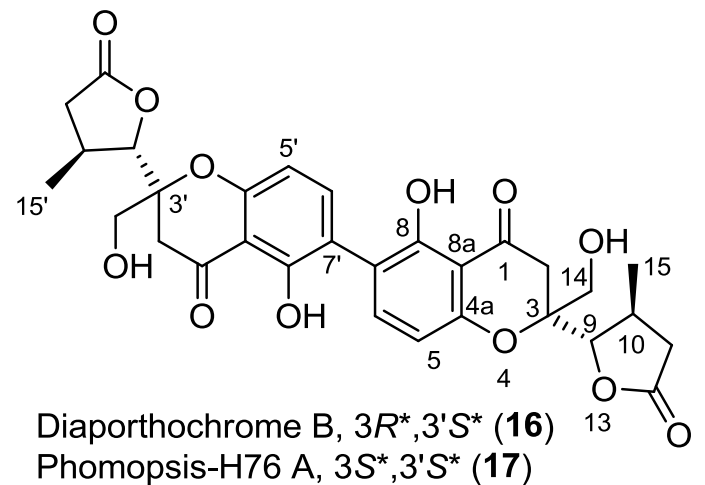

Phomopsis-H76 A, 3S*,3' $S^{*}(17)$

Isomers 13 and 14 shared a molecular formula, $\mathrm{C}_{36} \mathrm{H}_{37} \mathrm{O}_{15}$ (HRESIMS $m / z$ at $[\mathrm{M}+\mathrm{H}]^{+}: 709.2123$ for 13: 709.2137 for 14; calc'd 709.2132). Isolated as bright yellow solids, 13 was dereplicated as the dimer dicerandrol B [25]. Isomer 14 displayed similar chemical shifts in the ${ }^{1} \mathrm{H}$ NMR spectrum with dicerandrol B, and detailed analysis of gHMBC data failed to find a connectivity difference. However, the 2D ROESY spectrum tellingly found no correlation between H-5 ( $\delta 5.82)$ and hydroxymethyl $\mathrm{H}_{2}-12$ ( $\delta 5.02$ and 3.39), leading us to assign a trans relationship between $\mathrm{H}-5$ the hydroxymethine group on C-10a. Optical rotation of the two isomers are divergent, supporting their stereochemical isomerism $\left(14:[\alpha]_{\mathrm{D}}^{20}+12.6 ; 13:[\alpha]_{\mathrm{D}}^{20}-8.3\right.$ (our isolate, in $\mathrm{CHCl}_{3}$ ), $[\alpha]_{\mathrm{D}}^{25}-6.5$, reported in $\mathrm{CHCl}_{3}$ for dicerandrol B [25]). Interestingly the epimer 14 showed strong activity against $P$. falciparum with only moderate cytotoxicity, whereas dicerandrol B (13) failed to show either activity (Table 1). While the modest structural difference is difficult to rationalize as leading to the observed bioactivities, the change in sign of the optical rotation may suggest sufficient atropisomerism to make $\mathbf{1 4}$ a better receptor binder than 13.

Compound 15 was obtained from strain CY-5286 which was identified as Diaporthe sp., the same genus as that yielding dicerandrols. Like 13 and 14, compound 15 displayed a series of paired resonances in the ${ }^{13} \mathrm{C}$ NMR spectrum, although only 30 resonances were observed (Table 2). The molecular formula of $\mathrm{C}_{30} \mathrm{H}_{30} \mathrm{O}_{12}$ was determined by HRESIMS $\left([\mathrm{M}+\mathrm{H}]^{+}\right.$583.1842; $[\mathrm{M}+\mathrm{Na}]^{+}$ 
605.1630; calc'd for $\mathrm{C}_{30} \mathrm{H}_{31} \mathrm{O}_{12}$ 583.1816; calc'd for $\mathrm{C}_{30} \mathrm{H}_{30} \mathrm{NaO}_{12}$ 605.1635). However, 15 appeared to be a chromone, rather than xanthone, based on the presence of phenolic protons $\left(\delta_{\mathrm{H}} 12.28\left(8^{\prime}-\mathrm{OH}\right)\right.$, $11.73(8-\mathrm{OH})$ ), but lack of enolic protons, among other differences. It also differed from 13 and 14 in that it lacked acetyl groups. The ${ }^{1} \mathrm{H}$ NMR spectrum of $\mathbf{1 5}$ displayed aromatic signals on each of two monomeric units $\left(\delta_{\mathrm{H}-6} 7.25\right.$ and $\delta_{\mathrm{H}-7} 6.59 ; \delta_{\mathrm{H}-5^{\prime}} 6.50$ and $\left.\delta_{\mathrm{H}-6^{\prime}} 7.29\right)$, which correlated in the COSY spectrum and could be assigned as ortho disposed based on the 8.8 and $8.3 \mathrm{~Hz}$ coupling constant, respectively. Focusing on one monomeric unit at a time, H-6 showed HMBC correlation to two aromatic carbons bearing oxygen $\left(\delta_{\mathrm{C}-4 \mathrm{a}} 155.6\right.$ and $\left.\delta_{\mathrm{C}-8} 161.7\right)$, the latter of which proved to be a phenolic oxygen based on HMBC coupling from the $\delta_{\mathrm{H}} 11.73$ phenolic proton to $\delta_{\mathrm{C}-8} 161.7$. The $\mathrm{C}-8$ phenolic proton showed further HMBC correlation to C-7 $\left(\delta_{\mathrm{C}} 109.9\right)$ and $\mathrm{C}-8 \mathrm{a}\left(\delta_{\mathrm{C}} 107.0\right)$, and $\mathrm{H}-7$ $\left(\delta_{\mathrm{H}} 6.59\right)$ correlated with $\mathrm{C}-8 \mathrm{a}$ and $\mathrm{C}-5\left(\delta_{\mathrm{C}}\right.$ 115.2). That aromatic ring partial structure (Figure 4$)$ was further developed by observation of HMBC correlations of $\mathrm{H}-2 \mathrm{a}\left(\delta_{\mathrm{H}} 3.22\right)$ to $\mathrm{C}-8 \mathrm{a}$, the ketone carbon at $\mathrm{C}-1\left(\delta_{\mathrm{C}} 196.9\right)$, an oxygenated quaternary carbon $\left(\delta_{\mathrm{C}-3} 83.5\right)$, and with an oxygenated methine $\left(\delta_{\mathrm{C}-9} 86.9\right)$. That $\mathrm{H}-9\left(\delta_{\mathrm{H}} 4.22\right)$ anchored a $\gamma$-lactone to the chromone ring system was demonstrated through key HMBC correlations depicted in Figure 4.

Table 2. NMR data of diaporthochromones A (15), B (16) and phomopsis H76 A (17).

\begin{tabular}{|c|c|c|c|c|c|c|}
\hline \multirow[b]{2}{*}{ Position } & \multirow{2}{*}{$\begin{array}{r}15^{\mathrm{a}} \\
\delta_{\mathrm{H}}(J \text { in } \mathrm{Hz}) \\
\end{array}$} & \multicolumn{3}{|c|}{$16^{a}$} & \multicolumn{2}{|c|}{$17^{b}$} \\
\hline & & $\delta_{\mathrm{C}}$ & $\delta_{\mathrm{H}}$ (int., $J$ in $\mathrm{Hz}$ ) & $\delta_{\mathrm{C}}$ & $\delta_{\mathrm{H}}$ & $\delta_{\mathrm{C}}$ \\
\hline 1 & & 196.9 & & 195.9 & & 200.2 \\
\hline \multirow[t]{2}{*}{2} & $3.22(1 \mathrm{H}, \mathrm{d}, 17.5)$ & 38.3 & $3.05(1 \mathrm{H}, \mathrm{dd}, 17.6,0.8)$ & 37.9 & 3.11 & 39.9 \\
\hline & $2.86(1 \mathrm{H}, \mathrm{d}, 17.6)$ & & $2.90(1 \mathrm{H}, \mathrm{brd}, 15.1)$ & & 2.93 & \\
\hline 3 & & 83.5 & & $82.9 *$ & & 86.6 \\
\hline $4 a$ & & 155.6 & & 158.1 & & 161.5 \\
\hline 5 & & 115.2 & $6.45 *(1 \mathrm{H}, \mathrm{d}, 8.6)$ & 106.9 & 6.48 & 109.4 \\
\hline 6 & $7.25(1 \mathrm{H}, \mathrm{d}, 8.8)$ & 140.2 & $7.43 *(1 \mathrm{H}, \mathrm{d}, 8.5)$ & 140.8 & 7.38 & 142.7 \\
\hline 7 & $6.59(1 \mathrm{H}, \mathrm{d}, 8.8)$ & 109.9 & & 117.2 & & 118.8 \\
\hline 8 & & 161.7 & & 159.0 & & 160.6 \\
\hline $8 \mathrm{a}$ & & 107.0 & & $107.2 *$ & & 109.6 \\
\hline 9 & $4.22(1 \mathrm{H}, \mathrm{d}, 3.9)$ & 86.9 & $4.40(1 \mathrm{H}, \mathrm{dd}, 1.5,4.4)$ & $86.5 *$ & 4.37 & 89.3 \\
\hline 10 & $2.67(1 \mathrm{H}, \mathrm{m})$ & 29.6 & $2.84(1 \mathrm{H}, \mathrm{m})$ & 29.9 & 2.79 & 31.8 \\
\hline \multirow[t]{2}{*}{11} & $2.34(1 \mathrm{H}, \mathrm{dd}, 17.8,9.0)$ & 36.2 & $2.26(1 \mathrm{H}, \mathrm{m})$ & 36.5 & 2.75 & 38.6 \\
\hline & $2.00(1 \mathrm{H}, \mathrm{dd}, 18.1,5.4)$ & & $2.23(1 \mathrm{H}, \mathrm{m})$ & & 2.22 & \\
\hline 12 & & 176.0 & & 175.6 & & 178.7 \\
\hline \multirow[t]{2}{*}{14} & $3.95(1 \mathrm{H}, \mathrm{dd}, 5.6,11.6)$ & 62.9 & $3.94 *(2 \mathrm{H}, \mathrm{m})$ & 62.4 & 3.68 & 65.0 \\
\hline & $3.89(1 \mathrm{H}, \mathrm{dd}, 5.5,12.3)$ & & & & & \\
\hline 15 & $1.10(3 \mathrm{H}, \mathrm{d}, 6.8)$ & 20.5 & $1.27(3 \mathrm{H}, \mathrm{d}, 7.0)$ & 20.8 & 1.15 & 22.7 \\
\hline $1^{\prime}$ & & 197.0 & & 196.7 & & 200.2 \\
\hline \multirow[t]{2}{*}{$2^{\prime}$} & $3.24(1 \mathrm{H}, \mathrm{d}, 17.6)$ & 38.8 & $3.22(1 \mathrm{H}, \mathrm{d}, 17.6)$ & 38.2 & 3.11 & 39.9 \\
\hline & $3.10(1 \mathrm{H}, \mathrm{d}, 17.5)$ & & $2.96(1 \mathrm{H}, \mathrm{d}, 17.6,1.5)$ & & 2.93 & \\
\hline $3^{\prime}$ & & 83.3 & & $82.9 *$ & & 86.6 \\
\hline $4 a^{\prime}$ & & 158.5 & & 158.1 & & 161.5 \\
\hline $5^{\prime}$ & $6.50(1 \mathrm{H}, \mathrm{d}, 8.3)$ & 107.4 & $6.46 *(1 \mathrm{H}, \mathrm{dd}, 1.5,8.5)$ & 106.9 & 6.48 & 109.4 \\
\hline $6^{\prime}$ & $7.29(1 \mathrm{H}, \mathrm{d}, 8.3)$ & 140.1 & $7.44 *(1 \mathrm{H}, \mathrm{dd}, 1.5,8.5)$ & 140.8 & 7.38 & 142.7 \\
\hline
\end{tabular}


Table 2. Cont.

\begin{tabular}{|c|c|c|c|c|c|c|}
\hline $7^{\prime}$ & & 118.6 & & 117.2 & & 118.8 \\
\hline $8^{\prime}$ & & 158.4 & & 159.0 & & 160.6 \\
\hline $8 a^{\prime}$ & & 106.8 & & $107.0 *$ & & 109.6 \\
\hline $9^{\prime}$ & $4.33(1 \mathrm{H}, \mathrm{d}, 3.9)$ & 87.6 & $4.35(1 \mathrm{H}, \mathrm{dd}, 1.5,4.3)$ & $86.4 *$ & 4.37 & 89.3 \\
\hline $10^{\prime}$ & $2.95(1 \mathrm{H}, \mathrm{m})$ & 29.2 & $2.90(1 \mathrm{H}, \mathrm{m})$ & 29.4 & 2.79 & 31.8 \\
\hline \multirow[t]{2}{*}{$11^{\prime}$} & $2.88(1 \mathrm{H}, \mathrm{dd}, 18.0,10)$ & 36.4 & $2.90(2 \mathrm{H}, \mathrm{m})$ & 36.6 & 2.75 & 38.6 \\
\hline & $2.22(1 \mathrm{H}, \mathrm{dd}, 17.6,4.9)$ & & & & 2.22 & \\
\hline $12^{\prime}$ & & 175.3 & & 175.8 & & 178.7 \\
\hline \multirow[t]{2}{*}{$14^{\prime}$} & $3.82(2 \mathrm{H}, \mathrm{m})$ & 63.2 & $3.94 *(1 \mathrm{H}, \mathrm{m})$ & 62.8 & 3.68 & 65.0 \\
\hline & & & $3.86(1 \mathrm{H}$, brd, 11.7$)$ & & & \\
\hline $15^{\prime}$ & $1.30(3 \mathrm{H}, \mathrm{d}, 6.8)$ & 20.8 & $1.30(3 \mathrm{H}, \mathrm{d}, 6.4)$ & 20.6 & 1.15 & 22.7 \\
\hline $8-\mathrm{OH}$ & $11.73(1 \mathrm{H}, \mathrm{s})$ & & $12.01 *(1 \mathrm{H}, \mathrm{s})$ & & 11.97 & \\
\hline $8^{\prime}-\mathrm{OH}$ & $12.28(1 \mathrm{H}, \mathrm{brs})$ & & $12.00 *(1 \mathrm{H}, \mathrm{d}, 1.5)$ & & 11.97 & \\
\hline
\end{tabular}

${ }^{a}$ recorded in $\mathrm{CDCl}_{3}$ at $500 \mathrm{MHz}$ for ${ }^{1} \mathrm{H}$ and at $125 \mathrm{MHz}$ for ${ }^{13} \mathrm{C}$; ${ }^{\mathrm{b}}$ recorded in DMSO- $d_{6}$ at $500 \mathrm{MHz}$ for the ${ }^{1} \mathrm{H}$ and at $125 \mathrm{MHz}$ for ${ }^{13} \mathrm{C}$ [24]; * Interchangeable between monomeric units.

Figure 4. Selected HMBC and COSY correlations of $\mathbf{1 5 .}$

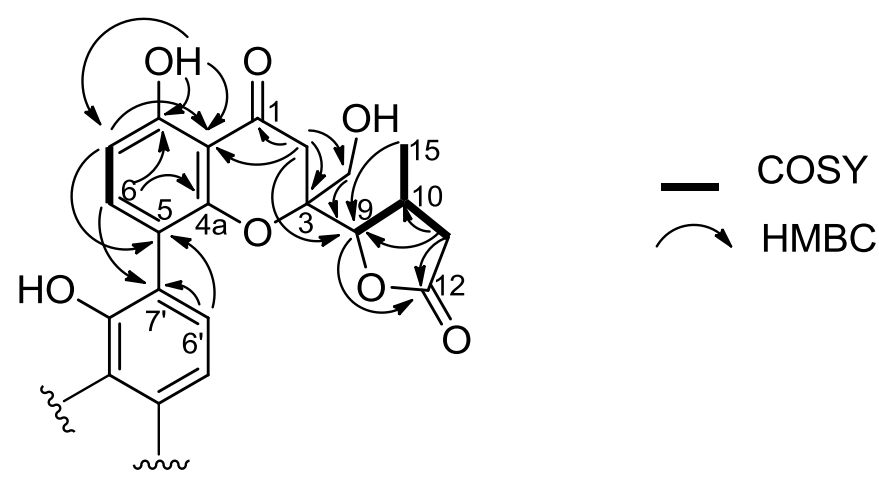

The second monomeric unit associated with compound 15 displayed largely the same HMBC correlations as that described above. The two units could be connected through observation of both H-6 $\left(\delta_{\mathrm{H}} 7.25\right)$ to $\mathrm{C}-7^{\prime}\left(\delta_{\mathrm{C}} 118.6\right)$ and $\mathrm{H}-6^{\prime}\left(\delta_{\mathrm{H}} 7.29\right)$ to $\mathrm{C}-5\left(\delta_{\mathrm{C}} 115.2\right) \mathrm{HMBC}$ correlations, defining a new dimeric chromone, diaporthochromone A (15). Significant chemical shift differences between $\gamma$-lactone chiral centers of each monomeric unit suggested an unsymmetrical nature of diaporthochromone A. The 2D ROESY spectrum clearly defined some stereochemical relationships: for example, both monomeric units show strong ROESY correlation between the H-9 methine and the $\mathrm{H}_{3}-15$ methyl groups, placing them on the same face (cis to one another) of the $\gamma$-lactone. That both monomeric units display $\mathrm{H}-10$ to $\mathrm{H}_{2}-14$ correlation in the ROESY requires that $\mathrm{H}-9$ and $\mathrm{H}_{3}-15$ both be on the opposing face from $\mathrm{H}_{2}-14$, reinforcing the $\mathrm{H}-9 / \mathrm{H}_{3}-15$ cis-relationship. The major difference between the two monomeric units is the relationship between $\mathrm{H}-9$ and $\mathrm{H}_{2}-2$ : In the monomeric unit bearing prime distinctions, there is no correlation between the two, while in the other there is, requiring a shift of $\mathrm{H}-9^{\prime}$ away from the dihydro- $\gamma$-pyrone ring system, which can only be achieved by an inverted stereocenter at C-9' compared to C-9. Thus we propose the relative stereochemistry for diaporthochromone A as $3 R^{*}, 9 S^{*}, 10 S^{*}, 3^{\prime} S^{*}, 9^{\prime} S^{*}, 10^{\prime} S^{*}$. 
A second compound was isolated from fungal strain CY-5286 as an isomer of diaporthochromone A (15). Diaporthochromone B (16) was demonstrated to have the molecular formula $\mathrm{C}_{30} \mathrm{H}_{30} \mathrm{O}_{12}$ based on HRESIMS $\left(\mathrm{m} / \mathrm{z}\right.$ at $[\mathrm{M}+\mathrm{H}]^{+} 583.1837$; calc'd for $\mathrm{C}_{30} \mathrm{H}_{31} \mathrm{O}_{12}$ 583.1816). A similar unsymmetrical $\gamma$-lactone-substituted chromone dimer was evident from the ${ }^{1} \mathrm{H}$ and ${ }^{13} \mathrm{C}$ NMR spectra (Table 2). Indeed, except for the two carbons C-5 and C-7, the NMR data is nearly superimposable. Distinguishing 16 are HMBC correlations for overlapping quaternary carbons at $\delta_{\mathrm{C}} 117.2\left(\mathrm{C}-7 / 7^{\prime}\right)$ from $\delta_{\mathrm{H}} 12.0\left(8 / 8^{\prime}-\mathrm{OH}\right)$, compared to 15 in which two signals are found near 117 , quaternary carbons $\delta_{\mathrm{C}-7^{\prime}}$ 118.6 and $\delta_{\mathrm{C}-5} 115.2$, only one of which $\left(\delta_{\mathrm{C}-7}, 118.6\right)$ correlates to a phenolic proton, $8^{\prime}-\mathrm{OH}$ in this case, at $\delta_{\mathrm{H}}$ 12.28. Instead, 15 displays two methine carbons at $\delta_{\mathrm{C}-7} 109.9$ and $\delta_{\mathrm{C}-5^{\prime}} 107.4$, in the vicinity of 16's overlapping C-5/5' $\left(\delta_{\mathrm{C}} 106.9\right)$, and one of them, $\delta_{\mathrm{C}-7} 109.0$, has HMBC correlation from the phenolic proton $8-\mathrm{OH}\left(\delta_{\mathrm{H}} 11.73\right)$. Thus, where 15 bears a phenolic proton that correlates by HMBC to an aromatic methine, $\mathbf{1 6}$ only has phenolic protons correlating to quaternary aromatic carbons. Diaporthochromone B (16) therefore bears a linear 7/7' coupled chromone ring system, analogous to the recently reported phomopsis-H76 A (17) [26]. That diaporthochromone B and phomopsis-H76 A are isomeric is evident from variations in the chemical shifts (Table 2), not all of which can be attributed to solvent effects, and their divergent optical rotations: $[\alpha]_{\mathrm{D}}^{20}\left(\mathrm{CHCl}_{3}\right)-24.1$ and $[\alpha]_{\mathrm{D}}^{25}(\mathrm{MeOH})+20$, respectively. A ROESY spectrum of 16 secured the cis-relationship of the 15/15' methyl groups and their corresponding H-9/9' methines, analogous to diaporthochromone A (described above) and phomopsis-H76 A. While a small sample size rendered the ROESY from 16 less informative from that of $\mathbf{1 5}$, the H-10 to H-2 correlation, in the absence of an analogous $\mathrm{H}-10^{\prime}$ to $\mathrm{H}-2^{\prime}$ correlation, supports an identical stereochemical assignment for the two.

\subsubsection{Lipids}

Two inactive lipids (Figure 5) were found in otherwise active extracts. (2E,4E)-Dimethyldeca-2, 4-dienoic acid (18) is a previously unreported compound which was found among active antimalarial cytochalasins from Xylaria sp. (strain CY-5331). Similarly, piliformic acid (19) [27] was found in strain CY-6884. Neither 18 nor 19 displayed activity against malaria. HRESIMS of 18 indicated a formula of $\mathrm{C}_{12} \mathrm{H}_{20} \mathrm{O}_{2}\left(\mathrm{~m} / \mathrm{z}\right.$ at $[\mathrm{M}+\mathrm{H}]^{+}$197.1545; calc'd 197.1542), which suggested three unsaturations. The ${ }^{13} \mathrm{C}$ NMR chemical shift data indicated carboxylic acid equivalent carbon at $\delta_{\mathrm{C}}$ 172.5. Sequential olefins followed: $\mathrm{H}-2\left(\delta_{\mathrm{H}} 5.82\right)$ showed correlations to the carboxylate, C-1, and to $\mathrm{C}-4\left(\delta_{\mathrm{C}} 126.5\right)$ in the HMBC spectrum. Correlations observed in the COSY spectrum between $\mathrm{H}-3$ $\left(\delta_{\mathrm{H}} 7.37\right)$ and $\mathrm{H}-2$ and $\mathrm{H}-4\left(\delta_{\mathrm{H}} 6.20\right)$, and $\mathrm{H}-4$ to $\mathrm{H}-5\left(\delta_{\mathrm{H}} 6.04\right)$, secured the $\mathrm{C}-1$ through $\mathrm{C}-5$ dienoate. $\mathrm{H}-5$, in turn, showed HMBC correlation to C-3 $\left(\delta_{\mathrm{C}} 147.7\right), \mathrm{C}-4\left(\delta_{\mathrm{C}} 126.5\right), \mathrm{C}-6\left(\delta_{\mathrm{C}} 35.0\right), \mathrm{C}-7\left(\delta_{\mathrm{C}} 43.8\right)$, and C-11 $\left(\delta_{\mathrm{C}}\right.$ 18.9). C-12 $\left(\delta_{\mathrm{C}} 20.9\right)$ is a methyl group substituted on C-8, as suggested by COSY correlation between $\mathrm{H}-12\left(\delta_{\mathrm{H}} 0.85\right)$ and $\mathrm{H}-8\left(\delta_{\mathrm{H}} 1.31\right)$. The terminal methyl protons $\mathrm{H}-10\left(\delta_{\mathrm{H}} 0.83\right)$ correlated to $\mathrm{C}-8\left(\delta_{\mathrm{H}} 1.31\right)$ and $\mathrm{C}-9\left(\delta_{\mathrm{H}} 1.14\right)$ by HMBC. The olefinic stereochemistry of 18 was deduced by analysis of coupling constants $\left(J_{2,3}=15.3 \mathrm{~Hz}\right.$ and $\left.J_{4,5}=15.2 \mathrm{~Hz}\right)$, supporting the trans,trans-relationship. The stereochemistry of the methyl substituents is unknown. 
Figure 5. Lipids from Chinese mangrove endophytes.

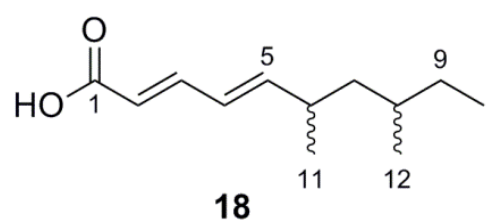<smiles>CCCCC/C=C(/C(=O)O)[C@H](C)C(=O)O</smiles>

\section{Experimental Section}

\subsection{General Experimental Procedures}

Optical rotations were measured on a Rudolph Research Analytical AUTOPOL IV digital polarimeter. IR and UV spectra were measured on Nicolete Avatar 320FT infrared and Hewlett-Packard 8452A diode array instruments, respectively. Medium pressure liquid chromatography was carried out on a Teledyne Isco Combiflash Companion using normal and reverse phase silica gel or $\mathrm{C}_{18}$ cartridges, respectively, purchased from Teledyne Isco. High performance liquid chromatography was carried out on semipreparative Phenomenex Luna $\mathrm{C}_{18}(2)$ reverse phase $(250 \times 10 \mathrm{~mm})$ and analytical $(250 \times 4.6 \mathrm{~mm})$ columns using a LC-20A Shimadzu multi-solvent delivery system, a CBM-20A Shimadzu system controller, and a SPD-M20A Shimadzu PDA detector. Low resolution mass spectra were recorded on an Agilent Technologies LC/MSD VL electrospray ionization mass spectrometer. High resolution mass spectra were recorded on an Agilent Technologies LC/MSD TOF electrospray ionization spectrometer. ${ }^{1} \mathrm{H}$ and ${ }^{13} \mathrm{C}$ NMR spectra were recorded on a Varian Inova instrument operating at $500 \mathrm{MHz}$ for ${ }^{1} \mathrm{H}, 125 \mathrm{MHz}$ for ${ }^{13} \mathrm{C}$, except 2D ROESY, which were acquired at $600 \mathrm{MHz}$ on a Varian Inova, using residual protonated solvent as ${ }^{1} \mathrm{H}$ internal standard or ${ }^{13} \mathrm{C}$ absorption lines of solvents for ${ }^{13} \mathrm{C}$ internal standard.

\subsection{Biological Materials}

Fungi were isolated from samples collected in mangroves of the South China Sea coast at Mai Po Nature Reserve, or from Hainan Island coastal regions. Segments of approximately $1-2 \mathrm{~mm}^{2}$ were plated on malt extract freshwater agar. Fungal growth was examined every day for two weeks and then twice a week for at least one month. A hypha growing out from the incubated plant tissue was cut out and transferred to a fresh malt extract agar plate [15]. Pure axenic endophytic fungal cultures were grown in the commonly used liquid medium which contained $1 \% \mathrm{w} / \mathrm{v}$ glucose, $0.1 \% \mathrm{w} / \mathrm{v}$ yeast extract and $0.2 \% \mathrm{w} / \mathrm{v}$ peptone for 3 weeks for the production of secondary metabolites; samples for crude extract preparation were $30 \mathrm{~mL}$ total volume each, while high priority samples were scaled up to $2 \mathrm{~L}$ total volume to support fractionation and characterization studies. Cultures were freeze dried and shipped expedited to USF.

\subsection{Dicerandrol D (14)}

From $6.4 \mathrm{~g}$ of freeze dried mycelia from Diaporthe sp. (strain CY-5188), a lipophilic (1:1 $\left.\mathrm{CH}_{2} \mathrm{Cl}_{2} / \mathrm{CH}_{3} \mathrm{OH}\right)$ extract was prepared and fractionated by MPLC and HPLC, using $2 \% \mathrm{CH}_{3} \mathrm{OH}$ in $\mathrm{CH}_{2} \mathrm{Cl}_{2}$ on silica gel, to yield $1.6 \mathrm{mg}$ of dicerandrol D (14). Yellow amorphous solid. $[\alpha]_{\mathrm{D}}^{20}+12.6$ 
(c $0.02 \mathrm{CHCl}_{3}$ ); ${ }^{1} \mathrm{H}$ NMR (500 MHz, $\mathrm{CDCl}_{3}$ ) $\delta_{\mathrm{H}} 14.23$ (enol, s, 1H), 13.98 (enol, s, 1H), 11.69 (phenol, s, 1H), 11.66 (phenol, s, 1H), $7.41(\mathrm{H}-3, \mathrm{~d}, J=8.9 \mathrm{~Hz}, 1 \mathrm{H}), 7.31\left(\mathrm{H}-3^{\prime}, J=8.8 \mathrm{~Hz}, 1 \mathrm{H}\right), 6.57$ (H-4, d, $J=8.9 \mathrm{~Hz}, 1 \mathrm{H}), 6.52\left(\mathrm{H}^{-} 4^{\prime}, \mathrm{d}, J=8.8 \mathrm{~Hz}, 1 \mathrm{H}\right), 5.83(\mathrm{H}-5, \mathrm{~s}, 1 \mathrm{H}), 5.61\left(\mathrm{H}-5{ }^{\prime}, \mathrm{s}, 1 \mathrm{H}\right), 5.03(\mathrm{H}-12, \mathrm{~d}$, $J=12.6 \mathrm{~Hz}, 1 \mathrm{H}), 4.01\left(\mathrm{H}-12^{\prime}, \mathrm{dd}, J=13.6,5.1 \mathrm{~Hz}, 1 \mathrm{H}\right), 3.62(\mathrm{H}-12, \mathrm{~d}, J=12.8 \mathrm{~Hz}, 1 \mathrm{H}), 3.39$ (H-12', $\mathrm{dd}, J=13.5,10.0 \mathrm{~Hz}, 1 \mathrm{H}), 2.56-2.29$ (H-6/6', H-7/7', m, 6H), 2.21 (H-14, s, 3H), 2.18 (H-14', d, 3H), $1.63\left(\mathrm{H}-16^{\prime}, \mathrm{s}, 3 \mathrm{H}\right), 1.07$ (H-11, d, $\left.J=6.2 \mathrm{~Hz}, 3 \mathrm{H}\right), 1.04\left(\mathrm{H}-11^{\prime}, \mathrm{d}, J=5.7 \mathrm{~Hz}, 3 \mathrm{H}\right) ;{ }^{13} \mathrm{C} \mathrm{NMR}$ $\left(125 \mathrm{MHz}, \mathrm{CDCl}_{3}\right) \delta_{\mathrm{C}} 187.9,187.5\left({\mathrm{C}-9 / 9^{\prime}}^{\prime}\right), 177.6,177.1\left(\mathrm{C}-8 / 8^{\prime}\right), 170.8,169.9\left(\mathrm{C}-13 / 13^{\prime}\right), 169.8$ (C-15'), 161.5, $161.3\left(\mathrm{C}-1 / 1^{\prime}\right), 154.1,154.1\left(\mathrm{C}-4 \mathrm{a} / 4 \mathrm{a}^{\prime}\right), 141.6,141.1\left(\mathrm{C}-3 / 3^{\prime}\right), 115.1,115.0\left(\mathrm{C}-2 / 2^{\prime}\right)$, 109.8, 108.8 (C-4/4'), 106.2, 106.0 (C-9/9'), 101.0, 99.7 (C-8a/8a'), 82.2, 80.9 (C-10a/10a'), 70.0, 70.0 $\left(\mathrm{C}-5 / 5^{\prime}\right), 65.2,65.4\left(\mathrm{C}-12 / 12^{\prime}\right), 33.4,33.4\left(\mathrm{C}-7 / 7^{\prime}\right), 28.1,27.7\left(\mathrm{C}-6 / 6^{\prime}\right), 21.1,21.0\left(\mathrm{C}-14 / 14^{\prime}\right), 17.7,17.6$ (C-11/11'), $20.1\left(\mathrm{C}-16^{\prime}\right)$; HRESIMS $m / z:[\mathrm{M}+\mathrm{H}]^{+}$709.2137, $[\mathrm{M}+\mathrm{Na}]^{+} 731.1967$ (calc'd for $^{\prime}$ $\mathrm{C}_{36} \mathrm{H}_{37} \mathrm{O}_{15}$ 709.2132, $\mathrm{C}_{36} \mathrm{H}_{36} \mathrm{NaO}_{15}, 731.1952$ ).

\subsection{Diaporthochromones $(\mathbf{1 5}$ and $\mathbf{1 6})$}

From $4.9 \mathrm{~g}$ of freeze dried mycelia from Diaporthe sp. (strain CY-5286), $2.1 \mathrm{~g}$ of lipophilic extract (1:1 $\mathrm{CH}_{2} \mathrm{Cl}_{2} / \mathrm{CH}_{3} \mathrm{OH}$ ) was fractionated first on normal phase MPLC using a $\mathrm{CH}_{2} \mathrm{Cl}_{2}$ gradient with increasing $\mathrm{CH}_{3} \mathrm{OH}$, then repeated HPLC (Figure S8) to achieve separation of $\mathbf{1 5}$ and 16, finally yielding 1.2 and $1.0 \mathrm{mg}$, respectively.

Diaporthochromone A (15): White amorphous solid. $[\alpha]_{\mathrm{D}}^{20}-84.6\left(c 0.1 \mathrm{CHCl}_{3}\right) ; \mathrm{CD}(c 0.01, \mathrm{MeOH})$ $\lambda_{\max } \mathrm{nm}(\varepsilon) 245$ (-30.5), $286(-22.7) ;{ }^{1} \mathrm{H}$ NMR and ${ }^{13} \mathrm{C}$ NMR (Table 2); HRESIMS $m / z:[\mathrm{M}+\mathrm{H}]^{+}$ 583.1842, $[\mathrm{M}+\mathrm{Na}]^{+} 605.1630$ (calc'd for $\mathrm{C}_{30} \mathrm{H}_{31} \mathrm{O}_{12}$ 583.1816; $\mathrm{C}_{30} \mathrm{H}_{30} \mathrm{NaO}_{12}$ 605.1635).

Diaporthochromone B (16): Yellow amorphous solid. $[\alpha]_{\mathrm{D}}^{20}-24.1$ (c $\left.0.1 \mathrm{CHCl}_{3}\right)$; $\mathrm{CD}$ ( $c$ 0.01 , $\mathrm{MeOH}) \lambda_{\max } \mathrm{nm}(\varepsilon) 250(+14.1), 293$ (4.2); ${ }^{1} \mathrm{H}$ NMR and ${ }^{13} \mathrm{C}$ NMR (Table 2); HRESIMS $\mathrm{m} / \mathrm{z}$ : $[\mathrm{M}+\mathrm{H}]^{+} 583.1837$ (calc'd for $\mathrm{C}_{30} \mathrm{H}_{31} \mathrm{O}_{12}$ 583.1816).

\section{5. (2E,4E)-6,8-Dimethyldeca-2,4-dienoic Acid (18)}

From $4.89 \mathrm{~g}$ of freeze dried CY-5331 mycelia, $2.06 \mathrm{~g}$ of lipophilic $\left(1: 1 \mathrm{CH}_{2} \mathrm{Cl}_{2} / \mathrm{CH}_{3} \mathrm{OH}\right)$ extract were obtained. Silica gel MPLC using 50\% EtOAc/hexane yielded 12 fractions, including a $226 \mathrm{mg}$ fraction 2. Fraction 2, after further MPLC (30\% EtOAc/hexane) and HPLC using 20\% EtOAc/hexane, yielded $7 \mathrm{mg}$ of 18. Yellow oil. $[\alpha]_{\mathrm{D}}^{20}-20.1\left(c 0.1 \mathrm{CHCl}_{3}\right) ;{ }^{1} \mathrm{H} \mathrm{NMR}\left(500 \mathrm{MHz}, \mathrm{CDCl}_{3}\right) \delta_{\mathrm{H}} 7.37(\mathrm{H}-3$, $\mathrm{dd}, J=15.3,10.9 \mathrm{~Hz}, 1 \mathrm{H}), 6.20(\mathrm{H}-4, \mathrm{dd}, J=15.2,10.9 \mathrm{~Hz}, 1 \mathrm{H}), 6.04(\mathrm{H}-5, \mathrm{dd}, J=15.2,8.3 \mathrm{~Hz}, 1 \mathrm{H})$, $5.82(\mathrm{H}-2, \mathrm{~d}, J=15.4 \mathrm{~Hz}, 1 \mathrm{H}), 2.38$ (H-6, m, 1H), $1.31\left(\mathrm{H}_{2}-7, \mathrm{H}-8, \mathrm{~m}, 3 \mathrm{H}\right), 1.14$ (H-9, m, 2H), 1.03 $(\mathrm{H}-11, \mathrm{~d}, J=6.6 \mathrm{~Hz}, 3 \mathrm{H}), 0.85(\mathrm{H}-12, \mathrm{~d}, J=7.3 \mathrm{~Hz}, 3 \mathrm{H}), 0.83\left(\mathrm{H}_{3}-10, \mathrm{~m}, 3 \mathrm{H}\right) ;{ }^{13} \mathrm{C} \mathrm{NMR}(125 \mathrm{~Hz}$, $\left.\mathrm{CDCl}_{3}\right) \delta_{\mathrm{C}} 172.5(\mathrm{C}-1), 152.0(\mathrm{C}-5), 147.7$ (C-3), 126.5 (C-4), 118.2 (C-2), 43.8 (H-7), 35.0 (C-6), 32.0 (C-8), 29.9 (C-9), 20.9 (C-12), 18.9 (C-11), 11.2 (C-10); HRESIMS m/z: [M + H] 197.1545, $[\mathrm{M}+\mathrm{Na}]^{+} 219.1365$ (calc'd for $\mathrm{C}_{12} \mathrm{H}_{21} \mathrm{O}_{2}, 197.1542 ; \mathrm{C}_{12} \mathrm{H}_{20} \mathrm{NaO}_{2}, 219.1361$ ). 


\subsection{Malaria Assay}

Malaria screening was conducted as previously reported [13].

\subsection{In Vitro Toxicity Assay}

Cell line A-549 (adenocarcinomic human alveolar epithelial cells) was cultured in F-12K Nutrient Mixture (Kaighn's Modification) media containing L-glutamine, supplemented with $10 \%$ fetal bovine serum and $1 \%$ penicillin-streptomycin. For the assay, A549 cells were diluted to $1.33 \times 105$ cells $/ \mathrm{mL}$ in DMEM F12 media with L-glutamine, without HEPES or phenol red, and supplemented with $2 \%$ fetal bovine serum and $1 \%$ penicillin-streptomycin. Test compounds at $2 \mathrm{mg} / \mathrm{mL}$ in DMSO were diluted 1:200 then serially diluted in duplicate over 11 concentrations. In 96-well plates, a volume of $90 \mu \mathrm{L} /$ well of A549 cells was added on top of $25 \mu \mathrm{L} /$ well of the test compound. Final concentration of A549 cells was 12,000 cells per well and the final starting concentration for test compounds was $10 \mu \mathrm{g} / \mathrm{mL}$. A Beckman-Coulter Biomek 3000 was used to dispense cells and prepare and dispense test compounds to the 96 well plates. Positive and negative controls were included on each assay plate. Plates were incubated for $72 \mathrm{~h}$ at $37{ }^{\circ} \mathrm{C}$ and $5 \% \mathrm{CO}_{2}$. After the incubation period, cell proliferation was assessed using Promega's CellTiter 96 Aqueous One Solution Cell Proliferation Assay reagent. Into each well $20 \mu \mathrm{L}$ of reagent was added followed by incubation for $3.5 \mathrm{~h}$ at $37{ }^{\circ} \mathrm{C}$ and $5 \% \mathrm{CO}_{2}$. A Molecular Devices Spectramax M2e plate reader was used to read absorbance at $490 \mathrm{nM}$. $\mathrm{IC}_{50}$ values were determined using a custom database manager (Dartaspects Corporation, Glencoe, CA, USA) by the use of nonlinear regression analysis.

\section{Conclusions}

A significant number of endophytic fungal extracts have been evaluated for antimalarial activity. The stringent bioassay restrictions used to advance extracts and fractions, using both malaria and cytotoxicity data, limited resource intensive scale-up and fractionation studies to roughly $1 \%$ of fungi studied. Nonetheless, the subset of fungal extracts described in this paper, derived from Hong Kong and Taiwan mangroves, yielded several new compounds, one of which, dicerandrol D (14), met our target criteria of nanomolar malaria activity with at least 10-fold less cytotoxicity.

\section{Acknowledgments}

This research was supported by Medicines for Malaria Venture, MMV08/0105. NMR and mass spectrometric facilities in the Center for Drug Discovery and Innovation were supported by a State of Florida Center of Excellence award. None of this work would have been possible without the relentless assistance of a number of dedicated undergraduate researchers, to whom we are indebted.

\section{Conflicts of Interest}

The authors declare no conflict of interest. 


\section{References}

1. Rateb, M.E.; Ebel, R. Secondary metabolites of fungi from marine habitats. Nat. Prod. Rep. 2011, 28, 290-344.

2. $\mathrm{Xu}, \mathrm{J}$. Biomolecules produced by mangrove-associated microbes. Curr. Med. Chem. 2011, 18, 5224-5266.

3. Wu, J.; Xiao, Q.; Xu, J.; Li, M.Y.; Pan, J.Y.; Yang, M.H. Natural products from true mangrove flora: Source, chemistry and bioactivities. Nat. Prod. Rep. 2008, 25, 955-981.

4. Omar, S.; Godard, K.; Ingham, A.; Hussain, H.; Wongpanich, V.; Pezzuto, J.; Durst, T.; Eklu, C.; Gbeassor, M.; Sanchez-Vindas, P.; et al. Antimalarial activities of gedunin and 7-methoxygedunin and synergistic activity with dillapiol. Ann. Appl. Biol. 2003, 143, 135-141.

5. Castillo, U.; Harper, J.K.; Strobel, G.A.; Sears, J.; Alesi, K.; Ford, E.; Lin, J.; Hunter, M.; Maranta, M.; Ge, H.; et al. Kakadumycins, novel antibiotics from Streptomyces sp. NRRL, 30566, an endophyte of Grevillea pteridifolia. FEMS Microbiol. Lett. 2003, 224, 183-190.

6. Isaka, M.; Suyarnsestakorn, C.; Tanticharoen, M.; Kongsaeree, P.; Thebtaranonth, Y. Aigialomycins A-E, new resorcylic macrolides from the marine mangrove fungus Aigialus parvus. J. Org. Chem. 2002, 67, 1561-1566.

7. Feller, I.C.; Lovelock, C.E.; Berger, U.; McKee, K.L.; Joye, S.B.; Ball, M.C. Biocomplexity in mangrove ecosystems. Annu. Rev. Mar. Sci. 2010, 2, 395-417.

8. Mangrove Forest Threats. Available online: http://wwf.panda.org/about_our_earth/blue_planet/ coasts/mangroves/mangrove_threats/ (accessed on 8 September 2013).

9. Alongi, D.M. Present state of future and the world's mangrove forests. Environ. Conserv. J. 2002, 29, 331-349.

10. Valiela, I.; Bowen, J.L.; York, J.K. Mangrove forests: one of the world's threatened major tropical environments. BioScience 2001, 51, 807-915.

11. Polidoro, B.A.; Carpenter, K.E.; Collins, L.; Duke, N.C.; Ellison, A.M.; Farnsworth, E.J.; Fernando, E.S.; Kathiresan, K.; Koedam, N.E.; Livingstone, S.R.; et al. The loss of species: Mangrove extinction risk and geographic areas of global concern. PLoS One 2010, 5, e10095.

12. Mace, G.M.; Norris, K.; Fitter, A.H. Biodiversity and ecosystem services: A multilayered relationship. Trends Ecol. Evol. 2011, 27, 19-26.

13. Lebar, M.D.; Hahn, K.N.; Mutka, T.; Maignan, P.; van Olphen, A.; Kyle, D.E.; McClintock, J.B.; Amsler, C.D.; Baker, B.J. CNS and antimalarial activity of synthetic meridianin and psammopemmin analogs. Bioorg. Med. Chem. 2011, 19, 5756-5762.

14. Kowalski, T.; Kehr, R.D. Endophytic fungal colonization of branch bases in several forest tree species. Sydowia 1992, 44, 137-168.

15. Pang, K.L.; Vrijmoed, L.L.P.; Goh, T.K.; Plaingam, N.; Jones, G.E.B. Fungal endophytes associated with Kandelia candel (Rhizophoraceae) in Mai Po Nature Reserve, Hong Kong. Bot. Mar. 2008, 51, 171-178.

16. Edwards, R.L.; Maitland, J.; Whalley, A.J.S. Metabolites of the higher fungi. Part 24. Cytochalasin N, O, P, Q, and R. New cytochalasins from the fungus Hypoxylon terricola Mill. J. Chem. Soc. Perkin Trans. I 1989, 57-65. 
17. Liu, J.; Jianwen, T.; Dong, Z.; Ding, Z.; Wang, X.; Liu, P. Neoengleromycin, a novel compound from Engleromyces goetzii. Helv. Chem. Acta 2002, 85, 1439-1442.

18. Espada, A.; Rivera-Sagredo, A.; de la Fuente, J.M.; Hueso-Rodriguez, J.A.; Elson, S.W. New cytochalasins from the fungus Xylaria hypoxylon. Tetrahedron 1997, 53, 6485-5492.

19. Konig, G.M.; Wright, A.D.; Angerhofer, C.K. Antimalarial diterpene isonitriles, isothiocyanates and isocyanates from the tropical marine sponge Cymbastela hooperi. J. Org. Chem. 1996, 61, 3259-3267.

20. Namikoshi, M.; Akano, K.; Meguro, S.; Kasuga, I.; Mine, Y.; Takahashi, T.; Kobayashi, H. A new macrocyclic trichothecene, 12,13-deoxyroridin E, produced by the marine-derived fungus Myrothecium roridum collected in Palau. J. Nat. Prod. 2001, 64, 396-398.

21. Pontius, A.; Mohamed, I.; Krick, A.; Kehraus, S.; Konig, G.M. Aromatic polyketides from marine algicolous fungi. J. Nat. Prod. 2008, 71, 272-274.

22. Kokubun, T.; Bridge, P.D.; Simmonds, M.S.J. Dihydroisocoumarins and a tetralone from Cytospora eucalypticola. Phytochemistry 2003, 62, 779-782.

23. Kamisuki, S.; Ishimaru, C.; Onoda, K.; Kuriyama, I.; Ida, N.; Sugawara, F.; Yoshida, H.; Mizushina, Y. Nodulisporol and nodulisporone, novel specific inhibitors of human DNA polymerase lambda from a fungus, Nodulisporium sp. Bioorg. Med. Chem. 2007, 15, 3109-3114.

24. Ma, W.S. Natural Product Drug Discovery against Tropical Diseases. Ph.D. Thesis, Department of Chemistry, College of Arts and Sciences, University of South Florida, Tampa, FL, USA, 11 November 2011.

25. Wagenaar, M.M.; Clardy, J. Dicerandrols, new antibiotic and cytotoxic dimers produced by the fungus Phomopsis longicolla isolated from an endangered mint. J. Nat. Prod. 2001, 64, 1006-1009.

26. Yang, J.F.; Xu, F. Huang, C.H.; Li, J.; She, Z.G.; Pei, Z.; Lin, Y.C. Metabolites from the mangrove endophytic fungus Phomopsis sp. (\#zsu-H76). Eur. J. Org. Chem. 2010, 2010, 3692-3695.

27. Anderson, J.R.; Edward, R.L.; Whalley, A.C.J. Metabolites of the higher fungi. Part 22. 2-Butyl-3-methylsuccinic acid and 2-hexylidene-3-methylsuccinic acid from xylariaceous fungi.

J. Chem. Soc. Perkin Trans. I 1985, 1481-1485.

(C) 2013 by the authors; licensee MDPI, Basel, Switzerland. This article is an open access article distributed under the terms and conditions of the Creative Commons Attribution license (http://creativecommons.org/licenses/by/3.0/). 